\title{
Bimodal felsic plutonism in the North Delhi fold belt, India
}

\author{
M.K. Khatatneh and M.K. Pandit \\ Department of Geology, University of Rajasthan \\ Jaipur 302004, India
}

\begin{abstract}
The late Proterozoic rocks of the Delhi Supergroup in the northern part of the Indian shield have undergone multiphase deformation and subsequent felsic plutonism. The magmatic activity in the Ajitgarh pluton in the North Delhi Fold Belt (NDFB) is characterized by a bimodal trondhjemite-granite association. This is the first report of trondhjemite occurrence in late Proterozoic environs from this region. The bimodal character of the suite as indicated by the field disposition and petrographic characters is also confirmed by statistical and geochemical parameters. The trondhjemite and granite represent two different pulses of felsic magmatism. These two types also demonstrate a time gap of emplacement and the evolution most probably took place through distinct trondhjemitic and calc-alkaline trend.
\end{abstract}

ABSTRACT

\section{INTRODUCTION}

The trondhjemite-granite association, a common feature of Archaean granite-greenstone terranes, is quite rare in the younger Proterozoic environs. In this paper the bimodal character of a late Proterozoic trondhjemite-granite suite from the northern part of the Indian shield is discussed. This is also the first reporting of the trondhjemite occurrence in this area.

\section{GEOLOGICAL SETTING}

The rocks of the Delhi Supergroup (in the northern part of the Indian shield) are contained in two separate domains, the North Delhi Fold Belt (NDFB) and South Delhi Fold Belt (SDFB). The Delhi Supergroup characterizes a volcanosedimentary association subsequently deformed and affected by felsic plutonism. The older magmatic activity $(1700-1500 \mathrm{Ma})$ is restricted to the NDFB whereas the younger ( $850-950 \mathrm{Ma})$ and the more widespread one is associated with SDFB (Chaudhary et al., 1984).

The NDFB further represents simultaneous deposition in three disconnected basins, the Bayana basin, Alwar basin and Khetri basin (from east to west). The present study has been carried out in the Ajitgarh pluton $\left(27^{\circ} 26^{\prime} \mathrm{N}: 75^{\circ} 50^{\prime} \mathrm{E}\right)$, a minor composite granitoid body intruding the metasediments composed of the sericite quartzite (Alwar Group) (Fig. 1). The contact relationship between the intrusives and country rock could not be studied due to the presence of wind blown sand and alluvium. The intrusive relationship of the granitoids with the country rocks is, however, established on the basis of their presence at different stratigraphic levels in the region (Roy and Das, 1985).

The Ajitgarh pluton is characterized by a trondhjemite-granite association representing different pulses of magmatic activity. The two granitoid types have a sharp contact with each other. volumetrically, the low trondhjemite rocks occupy the south-eastern part of the pluton whereas the major part of the body is granitic. Although both the granitoid phases appear to post date the deformation, the trondhjemite represents an older phase. The granitic tongues are seen within trondhjemite in the Ajitgarh pluton. In the nearby Barodia pluton also the trondhjemitic enclave are seen within the granites (Khatatneh, 1995).

Three phases of deformation have been recorded from the region (Das, 1988). The earliest DF1 deformation has resulted in NNE-SSW trending isoclinal folds coaxially refolded during DF2 deformation. The DF3 deformation, a milder phase, has resulted into roughly EW trending broad warps. 

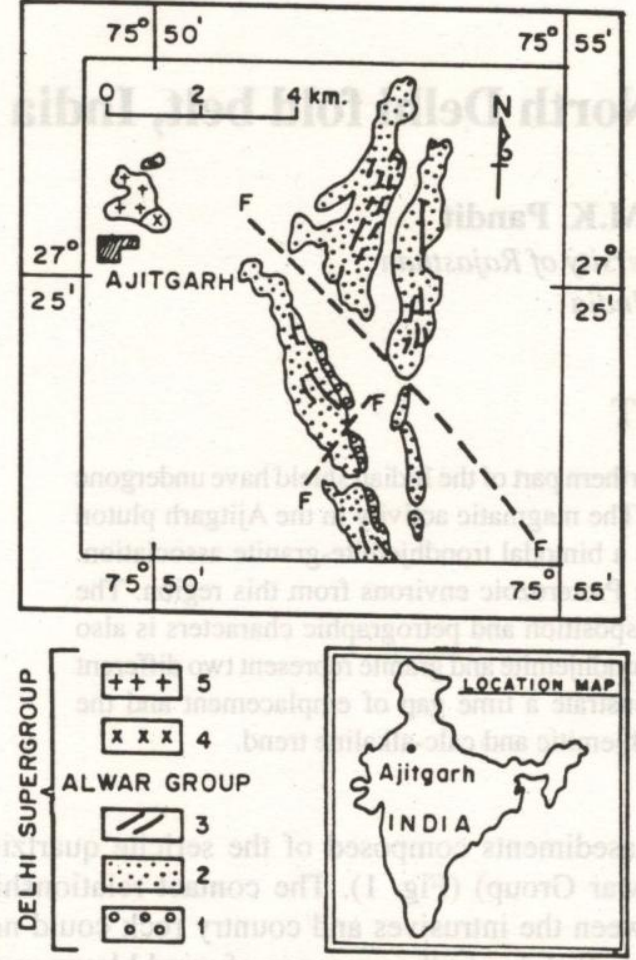

Fig. 1: Geological map showing disposition of Ajitgarh granitoids in relation to the regional stratigraphic framework. 1- conglomerate, 2- Sericite quartzite, 3Basic flows, 4- Trondhjemite and 5- Granite.

The intrusive activity appears to be a post deformation phenomenon as indicated by the absence of foliation and such other deformation induced planner fabric in the intrusive body.

\section{PETROGRAPHY AND MINERALOGY}

The Ajitgarh granitoids are medium to coarse grained and massive to porphyritic types. The trondhjemites are medium grained and leucocratic, whereas the granites are coarse grained and pink grey. The dominant minerals are quartz, alkali feldspar and plagioclase (albite) along with minor quantities of hornblende and biotite. The accessory minerals are allanite, zircon, sphene and ilmenite. Quartz grains are characterized by anhedral grain boundaries (often fractured), low relief and irregular and wavy extinction. Some tiny quartz grains are also present as inclusions within hornblende laths. The alkali feldspars are characterized by low relief, corroded grain margins and pronounced sericitization. The perthitic albite-potash feldspar intergrowth is also quite common in granites. Plagioclase $\left(A b_{10}\right.$ to $\left.A b_{20}\right)$ laths of subhedral outline demonstrate combined Carlsbad-Lamellar twinning. Alteration is also a common feature in plagioclase. In a few grains the sericitized core is mantled by alteration free rims indicating different growth stages. Hornblende, occurring as subhedral prisms, has one set of cleavage and strong pleochroism in the shades of deep bluish green to pale green. In a few granite samples growth of biotite along the cleavage planes and grain margins of hornblende can be attributed to retrograde metamorphism. Allanite, the most abundant accessory mineral is characterized by high relief, cauliflower like growth and moderate pleochroism varying from light pink brown to colourless. Tiny zircon crystals are present as inclusions within larger minerals.

On the basis of minerals and their relative proportion, the following mineralogical variants have been identified :

1. Trondhjemite (Hornblende - plagioclase, leucotrondhjemite)

2. Hornblende Granite

3. Biotite Hornblende Granite

4. Hornblende Biotite Granite

5. Biotite Granite

The mineralogical variants show a systematic field disposition and define a perfect mineralogical zoning of the pluton (Fig. 2). A systematic mineralogical variation from south to north (Serial No. 1 to 5 ) is indicated by a progressive increase in biotite and alkali feldspar and a corresponding decrease in hornblende and plagioclase. The trondhjemite is devoid of biotite and the biotite granite contains traces of hornblende. This indicates in situ differentiation of the pluton from the southern end. The variation of the mineral abundance is given as the average modal composition of mineralogical variants (Table 1).

\section{CLUSTER ANALYSIS}

The bimodal nature of the pluton as indicated by the petrographic and mineralogical characters is also verified statistically. The cluster analysis using complete linkages has been carried out due to its 
Bimodal felsic plutonism in the North Delhi fold belt, India

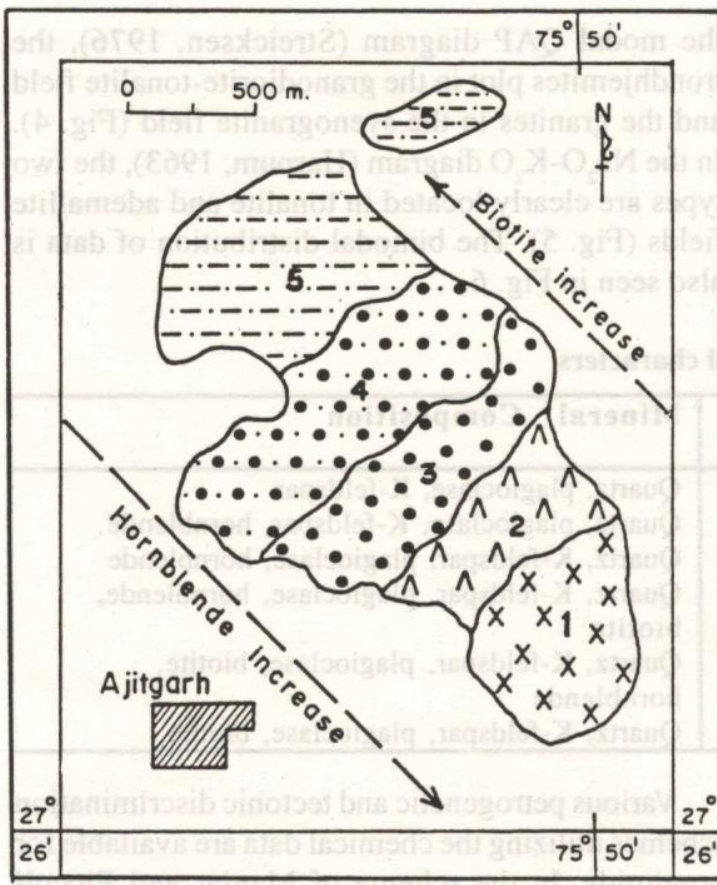

Fig. 2: Mineralogical zoning in Ajitgarh pluton. Note the inverse relationship between biotite and hornblende. Legend: 1-Trondhjemite, 2-Hornblende granite, 3- Biotite hornblende granite, 4- hornblende biotite granite and 5- biotite granite.

suitability to petrologic problems. The whole rock analysis of 29 samples has been subjected to cluster analysis, which is most suitable in locating natural groupings in a data set without prior assumptions (Le Maitre, 1982). The Euclidean distance $D i j$ between two samples $i$ and $j$ can be obtained from the following equation:

$$
\operatorname{Dij}=\sqrt{\sum_{k=1}^{m} \frac{(x i k-x j k)^{2}}{m}}
$$

where $m$ represents the number of variables (major oxides) and $x i k$ and $x j k$ are the values for $k^{\text {th }}$ variable for samples $i$ and $j$. The shorter the distance $D i j$, the greater is the similarity between the two samples. An $\mathrm{n} \times \mathrm{m}$ data matrix is converted into an $\mathrm{n} \mathrm{x} \mathrm{n}$ similarity matrix ( $\mathrm{n}=$ number of samples). The mutual minimum pairs are found and new distances between clustered and unclustered pairs are recalculated. Then, again reclustered till the matrix is reduced to a $2 \times 2$ level. The results of cluster analysis are shown as a dendrogram (Fig. 3).

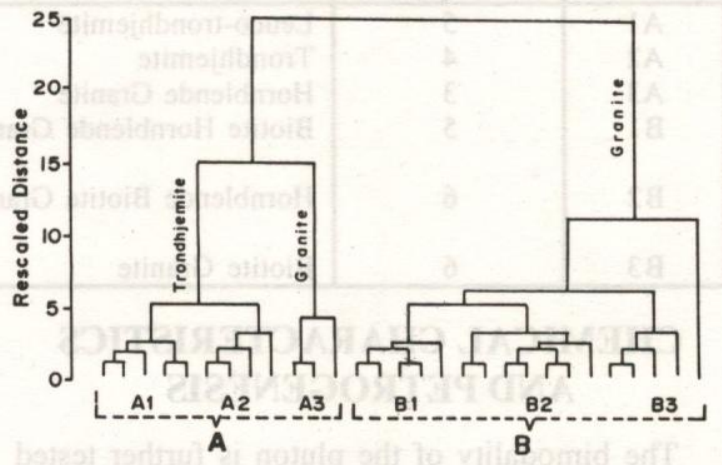

Fig. 3: Dendrogram showing two major clusters in the Ajitgarh granitoids.

The granitoids in the dendrogram define two major clusters, $\mathrm{A}$ and $\mathrm{B}$, which are further subdivided into various subclusters. Three subclusters (A1, A2 and A3) are identified in cluster A. The cluster B includes B1, B2 and B3. The trondhjemite samples are included in cluster $\mathrm{A} 1$ and $\mathrm{A} 2$ with hornblende trondhjemite and leuco-trondhjemite showing distinct affinity. The granites form the remaining clusters. The homogeneity of the two major clusters within themselves is evident by very short distances among subclusters. The clusters A1 and A2 do not differ much, but they are distinctly different with

Table 1: Average modal composition of mineralogical variants of Ajitgarh granitoids. The cluster numbers are same as given in Fig. 3.

\begin{tabular}{|c|c|c|c|c|c|c|}
\hline Mineral & $\begin{array}{c}\text { Leuco } \\
\text { Trondhjemite } \\
\mathbf{n}=\mathbf{5}\end{array}$ & $\begin{array}{c}\text { Hornblende } \\
\text { Trondhjemite } \\
\mathbf{n = 4}\end{array}$ & $\begin{array}{c}\text { Hornblende } \\
\text { Granite } \\
\text { n=4 }\end{array}$ & $\begin{array}{c}\text { Biotite Hornblende } \\
\text { Granite } \\
\text { n= } 5\end{array}$ & $\begin{array}{c}\text { Hornblende } \\
\text { Biotite Granite } \\
\text { n=5 }\end{array}$ & $\begin{array}{c}\text { Biotite } \\
\text { Granite } \\
\mathrm{n}=6\end{array}$ \\
\hline Cluster No & $\overline{\mathrm{A} 1}$ & $\mathrm{~A} 2$ & A3 & B1 & B2 & B3 \\
\hline Quartz & 46.0 & 40.0 & 36.0 & 34.0 & 33.5 & 33.0 \\
\hline K-Feldspar & 7.0 & 9.0 & 34.0 & 40.0 & 43.4 & 44.6 \\
\hline Plagioclase & 45.0 & 44.0 & 21.0 & 16.0 & 10.0 & 11.5 \\
\hline Biotite & 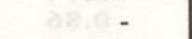 & 12:-4- & 1.0 & 4.5 & 6.2 & 9.0 \\
\hline Hornblende & 1.0 & 4.8 & 7.0 & 5.5 & 3.2 & 1.0 \\
\hline Allanite & 0.6 & 1.1 & 1.0 & 0.5 & 0.9 & 0.8 \\
\hline Opaque & 0.3 & 0.6 & - & - & 0.2 & 0.2 \\
\hline Others & 0.2 & 0.4 & - & - & 0.3 & 0.4 \\
\hline
\end{tabular}




\section{M.K. Khatatneh and M.K. Pandit}

remaining clusters. The cluster $\mathrm{A} 3$ is statistically distinct from $\mathrm{A} 1$ and $\mathrm{A} 2$. Petrographically also the subcluster A3 has a strong affinity to the cluster B. Thus, the bimodal character is also statistically substantiated as evident by a perfect correlation between different clusters and mineralogical characters (Table 2). the modal QAP diagram (Streicksen, 1976), the trondhjemites plot in the granodiorite-tonalite field and the granites in the syenogranite field (Fig. 4). In the $\mathrm{Na}_{2} \mathrm{O}-\mathrm{K}_{2} \mathrm{O}$ diagram (Harpum, 1963), the two types are clearly located in tonalite and ademallite fields (Fig. 5). The bimodal distribution of data is also seen in Fig. 6.

Table 2: Correlation of different clusters and mineralogical characters

\begin{tabular}{|c|c|l|l|}
\hline Cluster & $\begin{array}{c}\text { Number of } \\
\text { samples }\end{array}$ & Petrology & Mineral Composition \\
\hline A1 & 5 & Leuco-trondhjemite & Quartz, plagioclase, K-feldspar \\
A2 & 4 & $\begin{array}{l}\text { Trondhjemite } \\
\text { Hornblende Granite } \\
\text { A3 }\end{array}$ & $\begin{array}{l}\text { Quartz, plagioclase, K-feldspar, hornblende } \\
\text { Quartz, K-feldspar, plagioclase, hornblende } \\
\text { Quartz, K-feldspar, plagioclase, hornblende, } \\
\text { biotite Hornblende Granite } \\
\text { Quartz, K-feldspar, plagioclase, biotite, } \\
\text { hornblende } \\
\text { B2 }\end{array}$ \\
B3 & 6 & Hornblende Biotite Granite & Buartz, K-feldspar, plagioclase, biotite \\
\hline
\end{tabular}

\section{CHEMICAL CHARACTERISTICS AND PETROGENESIS}

The bimodality of the pluton is further tested for various chemical parameters. For this purpose, the average chemical analyses of different subclusters have been utilized. The major element data and the CIPW norms are given in Table 3 . In
Various petrogenetic and tectonic discrimination schemes utilizing the chemical data are available for granitoids. In the scheme of Maniar and Piccoli (1989), these granitoids define an anorogenic environment (Fig. 7). The trondhjemite samples plot in the orogenic field close to the boundary between the two fields. The diagram may have certain limitations for low potash granitoids.

Table 3: Average major element data for various sub-clusters (Fig. 3) for Ajitgarh granitoids (major element in wt. \% oxide). The CIPW norms and some important element ratios are also given.

\begin{tabular}{|c|c|c|c|c|c|c|}
\hline Cluster Nc & A 1 & A 2 & $\mathbf{A} 3$ & B 1 & B 2 & B 3 \\
\hline \multicolumn{7}{|c|}{ Major Oxide } \\
\hline $\mathrm{SiO}_{2}$ & 77.79 & 74.47 & 71.73 & 68.90 & 68.34 & 67.95 \\
\hline $\mathrm{TiO}_{2}$ & 0.33 & 0.38 & 0.31 & 0.36 & 0.39 & 0.40 \\
\hline $\mathrm{Al}_{2} \mathrm{O}_{3}$ & 12.24 & 12.69 & 13.54 & 13.56 & 13.69 & 13.63 \\
\hline $\mathrm{Fe}_{2} \mathrm{O}_{3}$ & 0.28 & 0.59 & 0.81 & 1.30 & 1.45 & 1.47 \\
\hline $\mathrm{FeO}$ & 0.69 & 1.43 & 1.96 & 3.02 & 3.53 & 3.57 \\
\hline $\mathrm{MnO}$ & 0.03 & 0.04 & 0.03 & 0.06 & 0.07 & 0.07 \\
\hline $\mathrm{MgO}$ & 0.14 & 0.42 & 0.62 & 0.95 & 1.00 & 0.98 \\
\hline $\mathrm{CaO}$ & 0.29 & 1.26 & 1.72 & 2.01 & 2.04 & 1.91 \\
\hline $\mathrm{Na}_{2} \mathrm{O}$ & 4.17 & 4.44 & 3.88 & 3.55 & 3.66 & 3.72 \\
\hline $\mathrm{K}_{2} \mathrm{O}$ & 1.53 & 1.51 & 4.41 & 4.49 & 4.47 & 4.43 \\
\hline Total & 97.44 & 98.23 & 99.01 & 98.20 & 98.34 & 98.13 \\
\hline \multicolumn{7}{|c|}{ CIPW Norms } \\
\hline Q & 46.55 & 38.78 & 26.99 & 24.00 & 23.88 & 22.06 \\
\hline Or & 9.06 & 8.95 & 26.06 & 26.53 & 26.42 & 26.18 \\
\hline $\mathrm{Ab}$ & 35.26 & 37.52 & 32.83 & 30.04 & 28.43 & 31.48 \\
\hline An & 1.45 & 6.25 & 6.51 & 7.81 & 9.07 & 7.41 \\
\hline C & 3.18 & 1.41 & - & SA - & & $614 \times 1-$ \\
\hline Di & 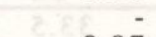 & - & & & 0.98 & - \\
\hline Hy & 0.97 & 2.62 & 3.15 & 5.43 & 6.81 & 6.37 \\
\hline $\mathrm{Mt}$ & 0.46 & 0.86 & 1.17 & 1.88 & 2.10 & 2.13 \\
\hline Il & 0.61 & 0.73 & 0.59 & 0.68 & 0.74 & 0.76 \\
\hline A/CNK & 1.09 & 1.09 & 0.93 & 0.86 & 0.86 & 0.93 \\
\hline A/NK & 1.33 & 1.33 & 1.2 & 1.2 & 1.2 & 1.2 \\
\hline $\mathrm{Na} 2 \mathrm{O} / \mathrm{K} 2 \mathrm{O}$ & 2.73 & 2.94 & 0.88 & 0.97 & 0.82 & 0.84 \\
\hline
\end{tabular}

1 Average of 5 samples of leuco trondhjemite. 4 . Average of 5 samples of biotite-hornblende granite.

2. Average of 4 samples of hornblende trondhjemite. 5. Average of 5 samples of hornblende-biotite granite.

3. Average of 3 samples of hornblende granites. 6. Average of 6 samples of biotite granite. 
Bimodal felsic plutonism in the North Delhi fold belt, India
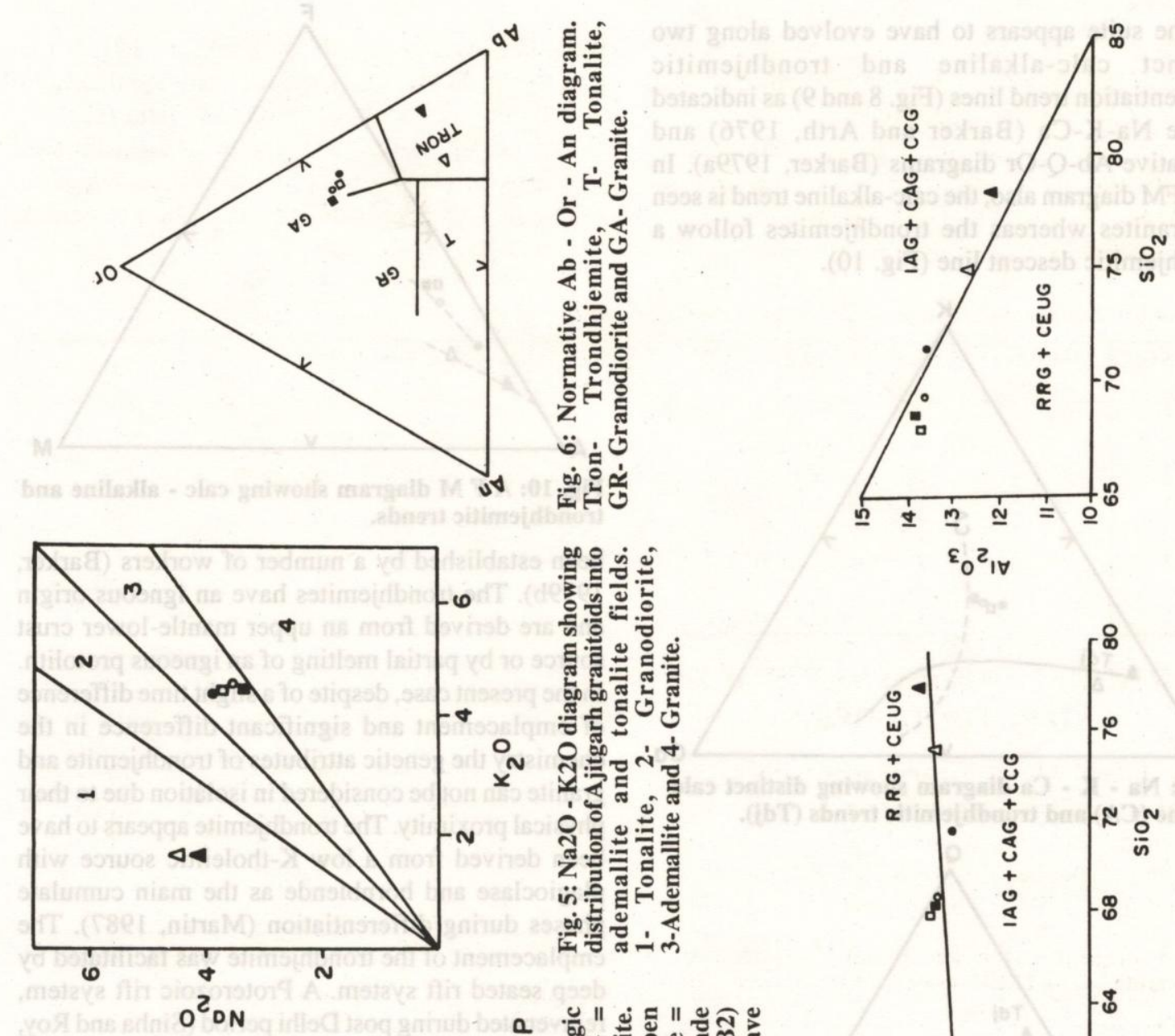

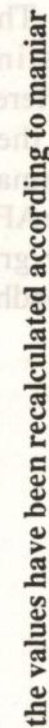

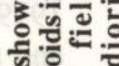

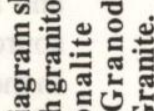

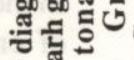

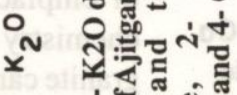

设.

î.

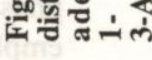
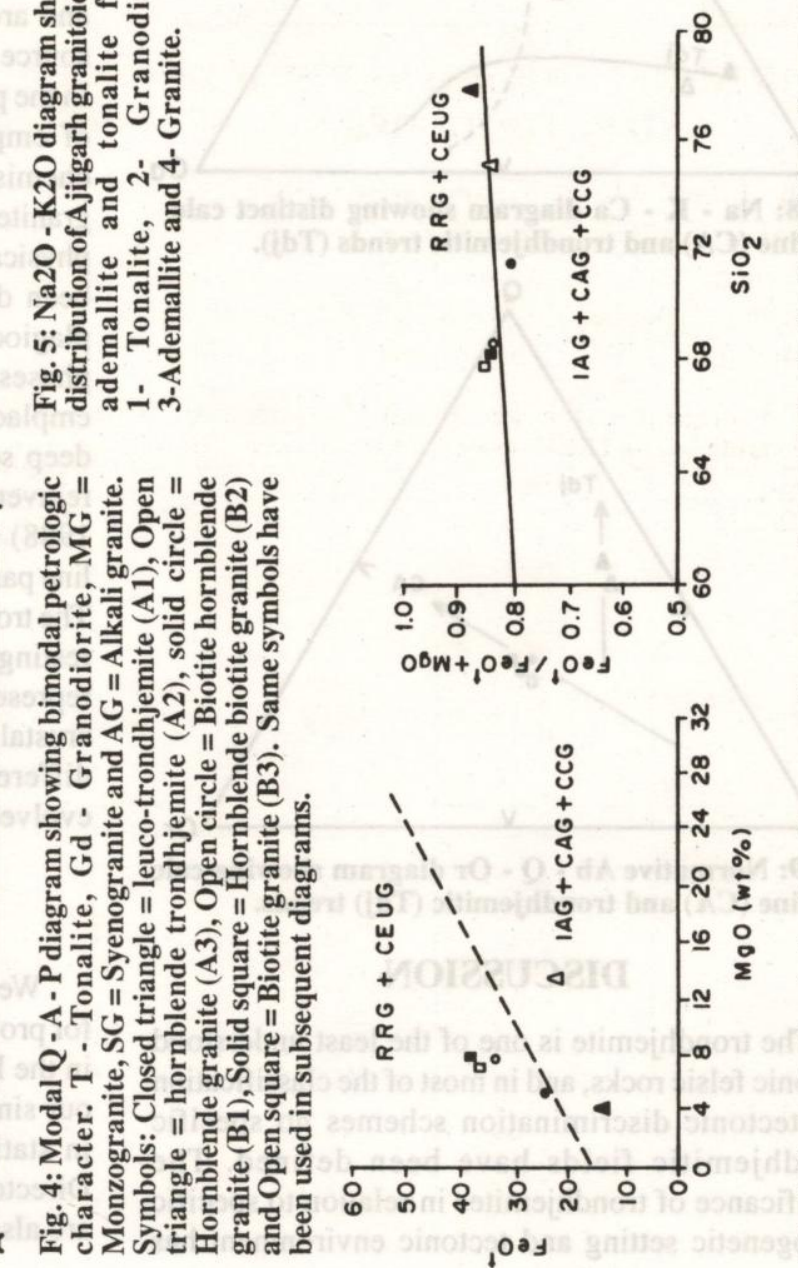


\section{M.K. Khatatneh and M.K. Pandit}

The suite appears to have evolved along two distinct calc-alkaline and trondhjemitic differentiation trend lines (Fig. 8 and 9) as indicated in the Na-K-Ca (Barker and Arth, 1976) and normative Ab-Q-Or diagrams (Barker, 1979a). In the AFM diagram also, the calc-alkaline trend is seen for granites whereas the trondhjemites follow a trondhjemitic descent line (Fig. 10).

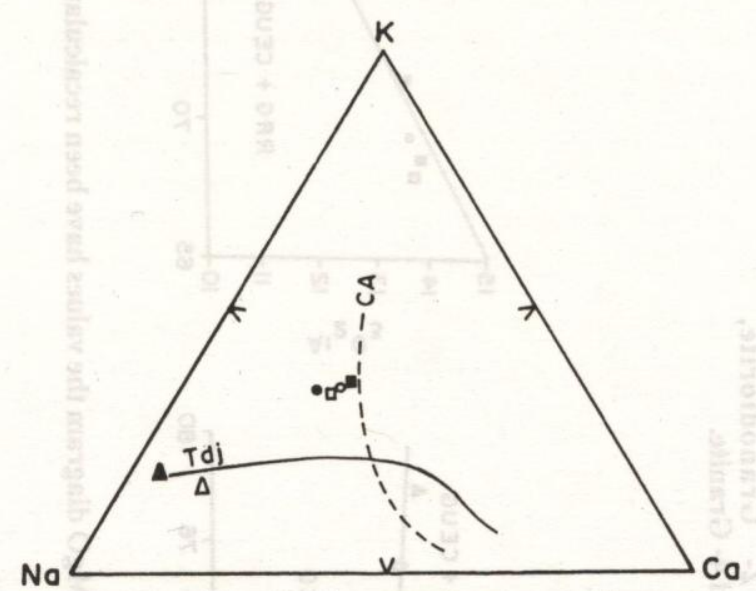

Fig. 8: $\mathrm{Na}-\mathrm{K}$ - Ca diagram showing distinct calc alkaline (CA) and trondhjemitic trends (Tdj).

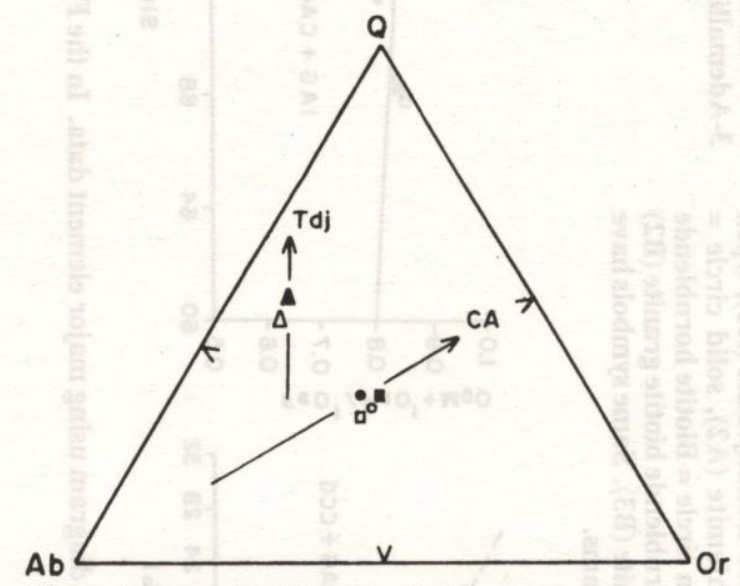

Fig. 9: Normative Ab - Q - Or diagram showing calc alkaline (CA) and trondhjemitic (Tdj) trends.

\section{DISCUSSION}

The trondhjemite is one of the least understood plutonic felsic rocks, and in most of the classification and tectonic discrimination schemes no specific trondhjemitic fields have been defined. The significance of trondhjemites in relation to specific petrogenetic setting and tectonic environment has

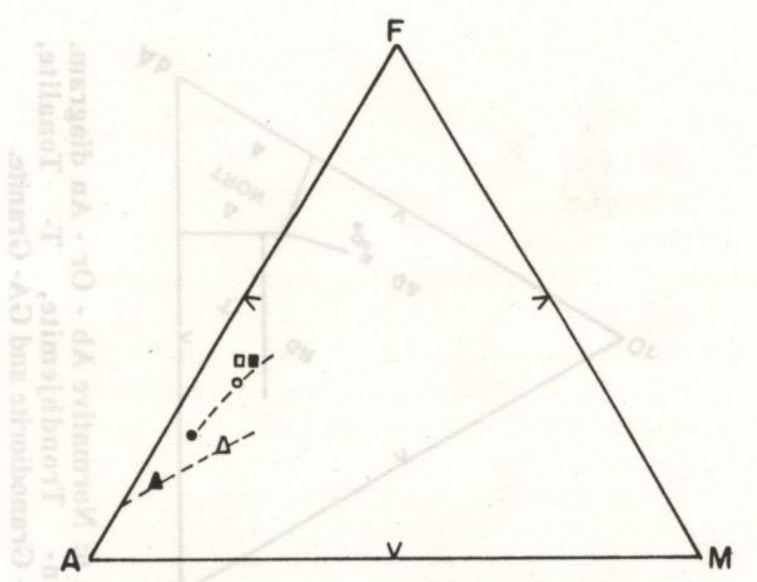

Fig. 10: A F M diagram showing calc - alkaline and trondhjemitic trends.

been established by a number of workers (Barker, 1979b). The trondhjemites have an igneous origin and are derived from an upper mantle-lower crust source or by partial melting of an igneous protolith. In the present case, despite of a slight time difference of emplacement and significant difference in the chemistry the genetic attributes of trondhjemite and granite can not be considered in isolation due to their physical proximity. The trondhjemite appears to have been derived from a low K-tholeiitic source with plagioclase and hornblende as the main cumulate phases during differentiation (Martin, 1987). The emplacement of the trondhjemite was facilitated by deep seated rift system. A Proterozoic rift system, rejuvenated during post Delhi period (Sinha and Roy, 1988 ) is indicated by a NNE-SSW trending albitite line passing to west of the Ajitgarh town (Ray, 1990). The trondhjemitic melt had no significant sub-crustal resting period before crystallization. The granites represent considerable interaction of the melt and crustal material. The two granitoid types represent different pulses of the same magmatic activity evolved through different paths.

\section{ACKNOWLEDGMENTS}

We are grateful to the Nepal Geological Society for providing us the opportunity to present this paper in the First Nepal Geological Congress. We extend our sincere thanks to Mr. R.K. Singhal for his help in statistical work. The facilities provided by the Director, Computer Center, University of Rajasthan, are also thankfully acknowledged. 


\section{REFERENCES}

Barker, F., 1979a, Trondhjemite: definition, environment and hypothesis of origin. In: F. Barker (ed.), Trondhjemite, dacite and related rocks. Elsevier, New York, pp. 1-12.

Barker, F., 1979b, Trondhjemites, dacite and related rocks. In: F. Barker (ed.), Elsevier, New York, 659 p.

Barker, F. and Arth, J.G., 1976, Generation of trondhjemite-tonalite liquids and Archaean bimodal trondhjemite-basalt suites. Geology, v. 4, pp. 596-600.

Chaudhary, A.L., Gopalan, K. and Sastry, C.A., 1984, Present status of geochronology of Precambrian rocks of Rajasthan. Tectonophysics, v. 105, pp. 131-140.

Das, A.R., 1988, Geometry of the superposed deformation in the Delhi Supergroup of rocks, north of Jaipur, Rajasthan. Mem. Geol. Soc. Ind., v. 7, pp. 247-266.

Harpum, J.R., 1963, Petrographic classification of granitic rocks in Tanganiyka by partial chemical analysis. Rec. Geol. Surv. Tanganiyka, v. 10, pp. 80-88.

Khatatneh, M.K., 1995, Geochemistry of Proterozoic granitoids from Barodia and Ajitgarh forming part of North Delhi Fold Belt in Rajasthan, India. Unpubl. thesis, University of Rajasthan, Jaipur, India, 147 p.
Le Maitre, R.W., 1982, Numerical petrology. Elsevier, Amsterdam, $281 \mathrm{p}$.

Maniar, P.D. and Piccoli, P.M., 1989, Tectonic discrimination of granitoids. Geol. Soc. Am. Bull., v. 101 , pp. 625-643.

Martin, H., 1987, Petrogenesis of Archaean trondhjemites, tonalites and granodiorites from eastern Finland: major and trace element chemistry. Jour. Petrol., v. 28, pp. 921-953.

Ray, S.K., 1990, The albitite line of northern Rajasthan: a fossil intracontinental rift zone. Jour. Geol. Soc. Ind., v. 36 , pp. 413-423.

Roy, A.B. and Das, A.R., 1985, A study of the time relations between movements, metamorphism and granite emplacement in the middle Proterozoic Delhi Supergroup of Rajasthan. Jour. Geol. Soc. Ind., v. 26, pp. 726-733.

Sinha and Roy, S., 1988. Proterozoic wilson cycles in Rajasthan. Mem. Geol. Soc. Ind., v. 7, pp. 95-108.

Streicksen, A.L., 1976, To each plutonic rock its proper name. Earth Sc. Reviews, v. 12, pp. 1-33. 